\title{
Feeding Activity, Salivary Amylase Activity, and Superficial Damage to Soybean Seed by Adult Edessa meditabunda (F.) and Euschistus heros (F.) (Hemiptera: Pentatomidae)
}

\author{
FAC SILva ${ }^{1}$, JJ da SILVA ${ }^{1}$, RA DepierI ${ }^{1}$, AR PanizzI ${ }^{2}$ \\ ${ }^{1}$ Embrapa Soja, Lab de Bioecologia de Percevejos, Londrina, PR, Brasil \\ ${ }^{2}$ Embrapa Trigo, Lab de Entomologia, Passo Fundo, RS, Brasil
}

\section{Keywords}

Cotyledon, damage, Glycine max, tetrazolium

\section{Correspondence}

Antônio Ricardo Panizzi, Embrapa Trigo, Lab de Entomologia, Caixa Postal 451, Passo Fundo, Rio Grande do Sul, Brasil; panizzi@cnpt.embrapa.br

Edited by Fernando L Cônsoli - ESALQ/USP

Received 21 October 2011 and accepted 28 May 2012

(C) Sociedade Entomológica do Brasil 2012

\begin{abstract}
Greenhouse and laboratory studies were conducted to evaluate feeding activity and superficial damage to soybean seed by the brown-winged stink bug, Edessa meditabunda (F.), and the Neotropical brown stink bug, Euschistus heros (F.). Soybean plants (cv. BRS 282), at R6 stage of development were used. Thirty pairs of each species were used individually for $48 \mathrm{~h}$. Two daily observations (9:00 AM and 3:00 PM) were taken to record the number of bugs (feeding/resting) on plant parts. Harvested seeds imbibed in tetrazolium solution were photographed for measurement of the damaged surface. Adult E. meditabunda significantly preferred soybean stems (19.7 bugs) to pods (2.7). Feeding/ resting was similar at 9:00 AM (mean number of 28.0 bugs) and 3:00 PM (24.3). Euschistus heros equally fed/stayed on stems (7.3 bugs) and pods (6.9), although most bugs (12.3) remained on the cage net; feeding/resting on all plant structures amounted to 13.7 bugs at 9:00 AM and 17.7 bugs at 3:00 PM. Amylase activity was greater for E. heros $(41.61 \pm 0.89 \mathrm{U} / \mathrm{mg})$ and almost none for E. meditabunda (2.35 \pm $0.14 \mathrm{U} / \mathrm{mg}$ ). The superficial damage to seeds was significantly greater for E. meditabunda $\left(22.9 \mathrm{~mm}^{2}\right)$ compared to E. heros $\left(12.5 \mathrm{~mm}^{2}\right)$. However, E. meditabunda caused less shrinkage of the seed tegument, while $E$. heros damage was deeper and seeds showed reduction in size.
\end{abstract}

\section{Introduction}

Feeding behavior and damage descriptions caused by different species of pentatomids to soybean, Glycine max, have been extensively reported (e.g., Daugherty et al 1964, Todd \& Turnipseed 1974, Panizzi et al 1979, McPherson et al 1993, Corrêa-Ferreira \& Azevedo 2002, Nunes \& Corrêa-Ferreira 2002, Panizzi 2004, Depieri \& Panizzi 2011). However, only few studies have been dedicated to the damage caused (Costa \& Link 1977, Galileo \& Heinrichs 1979) and the feeding behavior (Panizzi \& Machado-Neto 1992) of the brown-winged stink bug, Edessa meditabunda (F.). This species is the second most abundant pentatomid species on soybean in the Brazilian state of Rio Grande do Sul (Galileo et al 1977) and has often been observed in the central-west region of the country (ARP, personal observation). In the neighboring country of Argentina, it is considered an important pest of this crop (Rizzo 1971).

The Neotropical brown stink bug, Euschistus heros (F.), is a major component of the pentatomid-pest complex on soybean in Brazil. Once uncommon (Panizzi et al 1977), nowadays this stink bug is the most common species on this crop, even in areas where its occurrence was rare, such as in the state of Rio Grande do Sul (Pereira \& Salvadori 2008). Recently, E. heros was recorded on soybean in the Entre Ríos Province, Argentina (Saluso et. al 2011).

The high level of damage to seeds caused by pentatomids is related to their feeding behavior, morphology of mouth parts, and salivary enzymes (Depieri \& Panizzi 2010, 
2011). In this study, we compared the feeding/resting preference and behavior, and superficial damage to soybean seeds by the less studied $E$. meditabunda with that of the more common $E$. heros.

\section{Material and Methods}

\section{insect colony}

During March-May 2010, adults of E. heros and E. meditabunda were collected at the Embrapa (Empresa Brasileira de Pesquisa Agropecuária) Farm in Londrina Co., northern part of the state of Paraná, from soybean (Glycine max) fields. They were taken to the laboratory, placed in clear plastic boxes $(25 \times 20 \times 20 \mathrm{~cm})$, and provided with pods of green beans, Phaseolus vulgaris, raw shelled peanuts, Arachis hypogaea, and fruits (berries) of privet, Ligustrum lucidum (Oleaceae). Boxes were kept in an environmental chamber maintained at $25 \pm 1^{\circ} \mathrm{C}$ and $65 \pm 5 \% \mathrm{RH}$ and with a photoperiod of $16: 08$ (L:D).

\section{Feeding/resting preference and behavior of adults}

To compare the feeding/resting preference of stink bug adults for different plant parts, 10 pots with soybean plants (cv. BRS 282) at the R6 (pod-filling) stage of development were used. In the greenhouse $\left(29 \pm 2^{\circ} \mathrm{C}\right.$ ), pods (one pod with three seeds per cage) and stems were isolated within a small plastic cage $(6.0 \mathrm{~cm}$ diameter). Thirty pairs of each species of stink bug, randomly selected from the established laboratory colony, were placed individually in each cage. Two daily observations (9:00 AM and 3:00 PM) were taken, and the number of bugs either feeding or resting on the different plant parts was recorded during $48 \mathrm{~h}$. Based on our preliminary experiments, this time interval was consider the most adequate to observe for damage induced by stinkbug feeding. Because we did not record whether the bugs were or not with their stylets inserted in the plant parts, we consider that they were either feeding or just resting on the plant structures in which they were observed at. Also, the position of the bugs feeding/resting on the stems was recorded. Then, insects were removed; plants were individually covered with a voile cage, and kept in the greenhouse $\left(29 \pm 2^{\circ} \mathrm{C}\right)$ up to maturation (R8 stage). Seeds were hand harvested and taken to the laboratory for visual analysis of damage.

\section{Amylase activity in salivary glands extracts}

Saliva of field-collected adults of $E$. meditabunda and of $E$. heros ( $n=80$ bugs for each species) fasted for $24 \mathrm{~h}$ in the laboratory was obtained by dissection of the salivary glands. Glands were dissected in cooled $0.3 \%$ sodium chloride $(\mathrm{NaCl})$ saline solution at 5 to $12^{\circ} \mathrm{C}$, washed two times, externally dried using absorbent paper, placed in $1.5 \mathrm{ml}$ vials, and kept on ice before storage in an ultra freezer $\left(-80^{\circ} \mathrm{C}\right)$. To collect the saliva for evaluation of the amylase activity, glands were grounded with a pestle, centrifuged $(20,000 \times g)$ for $10 \mathrm{~min}$ at $4^{\circ} \mathrm{C}$, and the supernatant recovered. The supernatant from $E_{\text {. meditabunda }}(500 \mu \mathrm{l})$ was diluted $10 \times$ with deionized water, and the one from $E$. heros $(200 \mu \mathrm{l})$ diluted $30 \times$ to increase the sample volumes.

Amylase activity was determined with the soluble starch substrate diluted in a sodium diphosphate buffer $(1 \% \mathrm{w} / \mathrm{v}$; pH 7.0) (Noelting \& Bernfeld 1948). The substrate digestion was done with diluted supernatants incubated at $30 \pm 1^{\circ} \mathrm{C}$ in assay tubes. The enzymatic reaction was stopped at 60 , 120,180 , and $240 \mathrm{~min}$ after heat exposure $\left(95^{\circ} \mathrm{C}\right.$ for $\left.3 \mathrm{~min}\right)$; 3.5-dinitrosalicylic acid (DNS) was added, and the samples were boiled for $5 \mathrm{~min}$. The DNS was used to determine the resulting reducing sugars at $550 \mathrm{~nm}$ in a light spectrophotometer at each interrupted reaction time. Regression analyses of the absorbance values were used to calculate the amylase activity. Each treatment was replicated three times. Results of the amylase activity are expressed in U/ $\mathrm{mg}$ of protein, and one unit (U) is the amount of enzyme that hydrolyzes one $\mu \mathrm{mol}$ of substrate bonds per minute (International Union of Biochemistry 1961). Protein content of the salivary gland extract was determined by using a commercial solution based on the Bradford assay, the Coomassie Protein Assay (Pierce Co.), using albumin as a protein standard.

\section{Seed damage analyses}

In the laboratory, 30 mature seeds that were exposed to each species of stink bug tested plus the control (seeds from uninfested plants) were randomly selected and kept in a germination chamber $\left(25 \pm 1^{\circ} \mathrm{C}\right)$ for $24 \mathrm{~h}$. This time

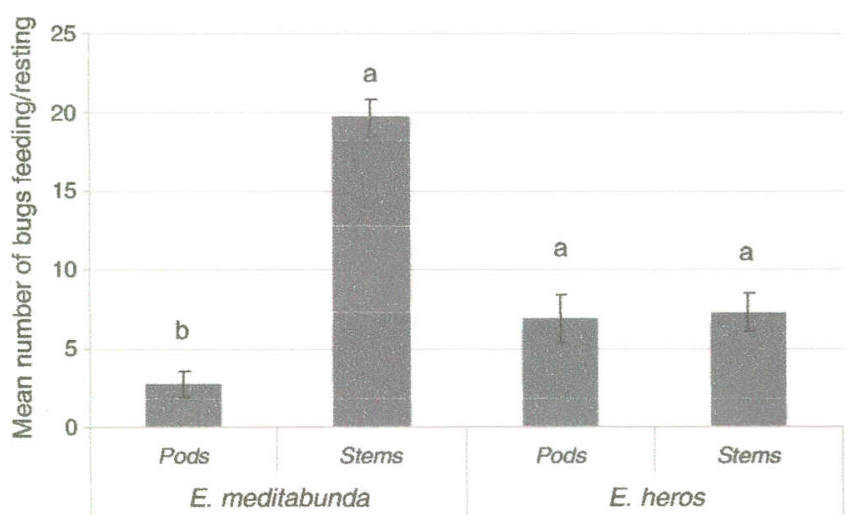

Fig 1 Mean number ( $₫$ SEM) of adult stink bugs on soybean plant (pods or stems, feeding/resting) caged in the greenhouse. Means followed by the same letter (within each species) do not differ significantly using the Tukey test ( $P>0.01)$. 


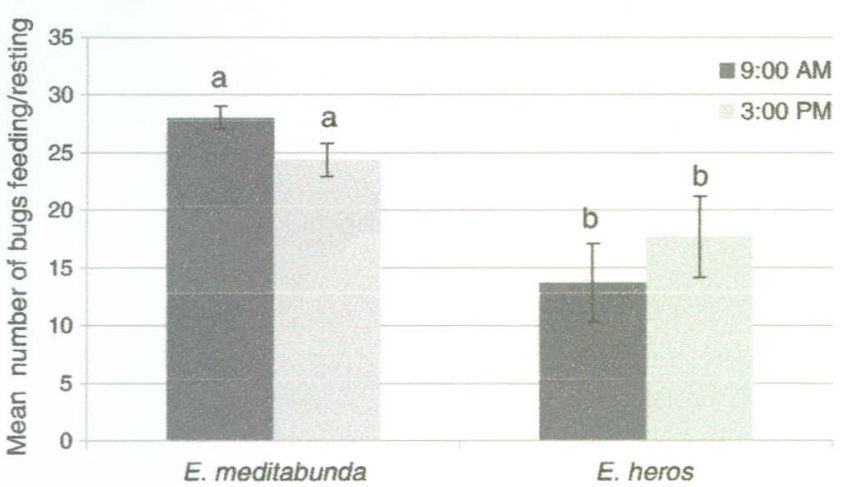

Fig 2 Mean number ( \pm SEM) of adult stink bugs on soybean plant (pods or stems, feeding/resting) caged in the greenhouse. Means followed by the same letter (within each species) do not differ significantly using the Tukey test $(P>0.01)$.

allowed the bioactivity of the salivary enzymes injected by the bugs to produce the damage. Tetrazolium $(2,3,5$ triphenyl tetrazolium chloride) was added to the entire seed to obtain color contrast of the seed damaged area (França-Neto et al 1998). Each seed was photographed using the standard $20 \times 20 \mathrm{~mm}$ square of the
Photop software (IAPAR, Londrina, PR, Brazil) for measurement of the superficial damaged area

\section{Statistics}

Data on the feeding/resting and on the damaged seed area were submitted to ANOVA (SAS Institute Inc. 1998). When appropriate, data were transformed to arc $\sin \sqrt{ } x / 100$ for analysis and means were compared using the Tukey test $(P \leq 0.01)$.

\section{Results and Discussion}

\section{Feeding/resting preference}

In both observation periods (9:00 AM and 3:00 PM), E. meditabunda significantly $(P \leq 0.01)$ preferred to feed/stay on soybean stems (mean $=19.7$ bugs) than on pods (2.7; Fig 1). Euschistus heros equally fed/stayed on stems (7.3 bugs) and pods (6.9), although most insects (12.3 bugs) were recorded on the cage net.

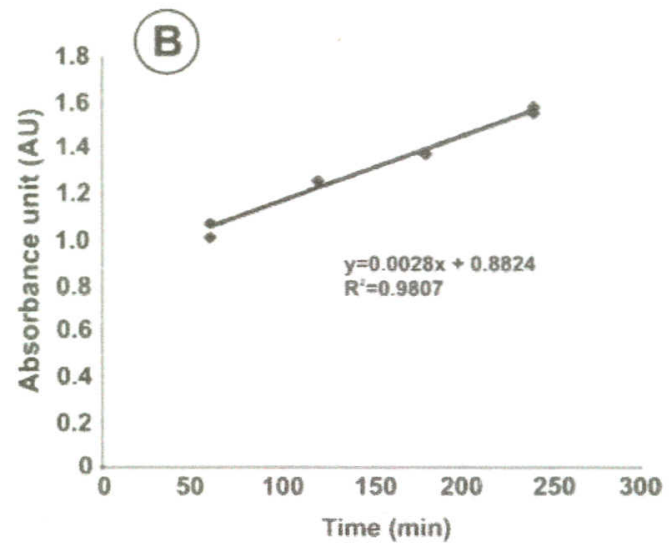

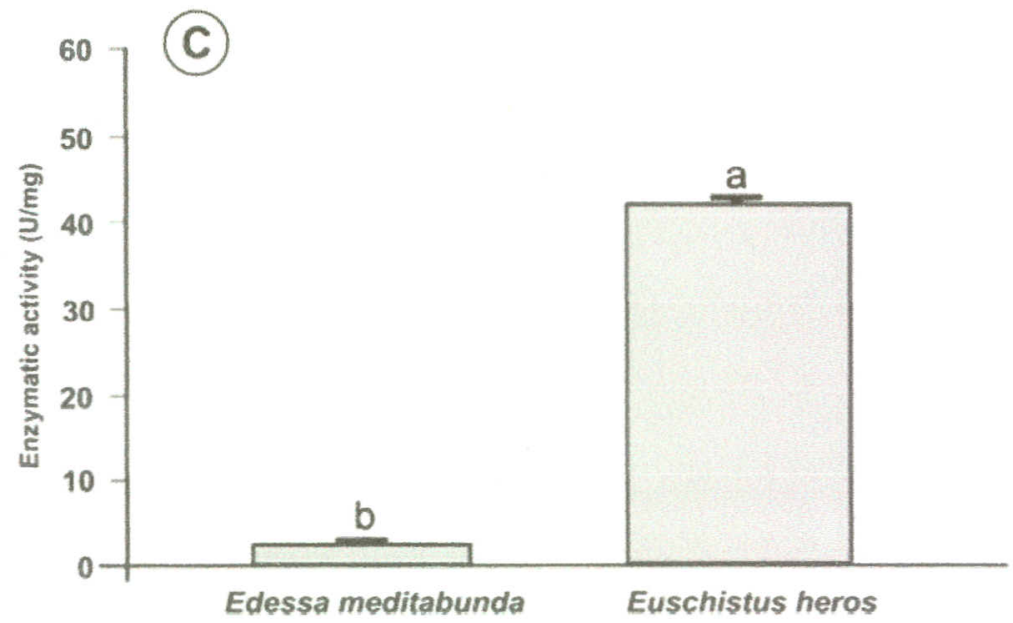

Fig 3 Amylase activity in salivary glands extracts of Edessa meditabunda (a), and of Euschistus heros (b) measured in absorbance vs. time, and in $\mathrm{U} / \mathrm{mg}(\mathrm{c}) ; n=3$. Means followed by the same letter do not differ significantly using the Tukey test $(P>0.01)$. 
Table 1 Mean ( \pm SEM) area $\left(\mathrm{mm}^{2}\right)$ and percentage of superficial damage to soybean seeds attacked by adult Edessa meditabunda and Euschistus heros during $48 \mathrm{~h}$, in cages in the greenhouse.

\begin{tabular}{llll}
\hline $\begin{array}{l}\text { Stink bug } \\
\text { species }\end{array}$ & $\begin{array}{l}\text { Cotyledon } \\
\text { area }\left(\mathrm{mm}^{2}\right)^{\text {ns }}\end{array}$ & $\begin{array}{l}\text { Superficial } \\
\text { damage area } \\
\left(\mathrm{mm}^{2}\right)^{\mathrm{a}}\end{array}$ & $\begin{array}{l}\text { Percentage } \\
\text { of damage }\end{array}$ \\
\hline $\begin{array}{l}\text { Edessa meditabunda } \\
(n=11)\end{array}$ & $75.6 \pm 2.40$ & $22.9 \pm 6.42 \mathrm{a}$ & $30.1 \pm 8.40 \mathrm{a}$ \\
$\begin{array}{l}\text { Euschistus heros } \\
(n=62)\end{array}$ & $72.8 \pm 1.71$ & $12.5 \pm 1.09 \mathrm{~b}$ & $18.4 \pm 1.70 \mathrm{~b}$ \\
\hline
\end{tabular}

ns nonsignificant.

${ }^{a}$ Means in each column followed by the same letter do not differ significantly using the Tukey test $(P>0.01)$.

${ }^{b}$ Percentage data were transformed by arc $\sin v x / 100$ for analysis.

The number of bugs on the different plant structures (pods or stems, feeding or not) at 9:00 AM was significantly greater for $E$. meditabunda (mean number of 28.0 bugs) as compared with $E$. heros (13.7 bugs). At 3:00 PM, a similar trend was observed with 24.3 E. meditabunda vs. 17.7 E. heros recorded on plant structures (Fig 2). No differences were found in the number of bugs observed on pods or stems within the same bug species between the two observation periods.

The greater number of $E$. meditabunda on plant structures as compared to $E$. heros is probably related to the different feeding habits of these bugs; the former is known to prefer soybean stems (Galileo \& Heinrichs 1979) and vegetative tissue of potato plants (Rizzo 1971), while the later feeds mostly on pods (Villas Bôas \& Panizzi 1980). Because stems provide much less nutrients than pods containing seeds, $E$. meditabunda needs to feed longer on stems to obtain its needed nutrients, and therefore, stay longer on the plants. Euschistus heros, by preferring pods, need less time to stay on the plant, which explains the greater number of bugs recorded on the cage net. In addition, this behavior of moving to the net of the cage could be attributed to a more restless behavior of the last species.

\section{Amylase activity in salivary glands extracts}

Amylase activity in the salivary glands extract was relatively low compared to what has been reported in the literature (Hori 1972), indicating low concentration of this enzyme in the salivary glands. Regression analyses of the absorbance values vs. time used to calculate the amylase activity was positively correlated for E. heros (Fig 3 b), but no correlation was found for E. meditabunda (Fig 3a). Amylase activity from salivary glands of $E$. heros was 20 times higher than that obtained from salivary extracts of $E$. meditabunda (Fig 3c).

Amylase activity has been reported for over 70 species of heteropterans, mostly mirids and pentatomids (Hori 2000). Although some reports in the literature are doubtful due to questionable methods used (Taylor \& Miles 1994) or contamination of whole glands by hemolymph enzymes or microbes during enzyme extraction (PW Miles communication to $\mathrm{K}$. Hori in Hori 2000), amylase is an important enzyme in the salivary glands of most phytophagous heteropterans.

The high amylase activity detected from salivary gland extracts of $E$. heros as compared to the almost undetected amylase activity in E. meditabunda, may be explained by their feeding preferences. Euschistus heros feeds mostly on starch-rich substrates as the reproductive structures (seeds), while E. meditabunda prefers to feed on a starch-poor substrate as the vegetative tissues (stems). However, further research is needed to fully confirm this hypothesis.

\section{Superficial damage to soybean seeds}

The superficial damage (area) to seeds was significantly $(P \leq 0.01)$ greater for $E$. meditabunda $\left(22.89 \mathrm{~mm}^{2}\right)$ if compared to $E$. heros $\left(12.47 \mathrm{~mm}^{2}\right)$, reaching approximately $30 \%$ of the total area of the cotyledon, as opposed to ca. $18 \%$ for $E$. heros (Table 1). Smaller superficial damage was
Fig 4 Mature soybean seeds (R8) attacked by adult Edessa meditabunda and Euschistus heros, at R6 stage, and not attacked (control). Soybean cotyledons treated with tetrazolium showing damage by Edessa meditabunda with a dark pink stain widespread (a); damage by Euschistus heros with deep tissue necrosis (b); and seed without damage (c).
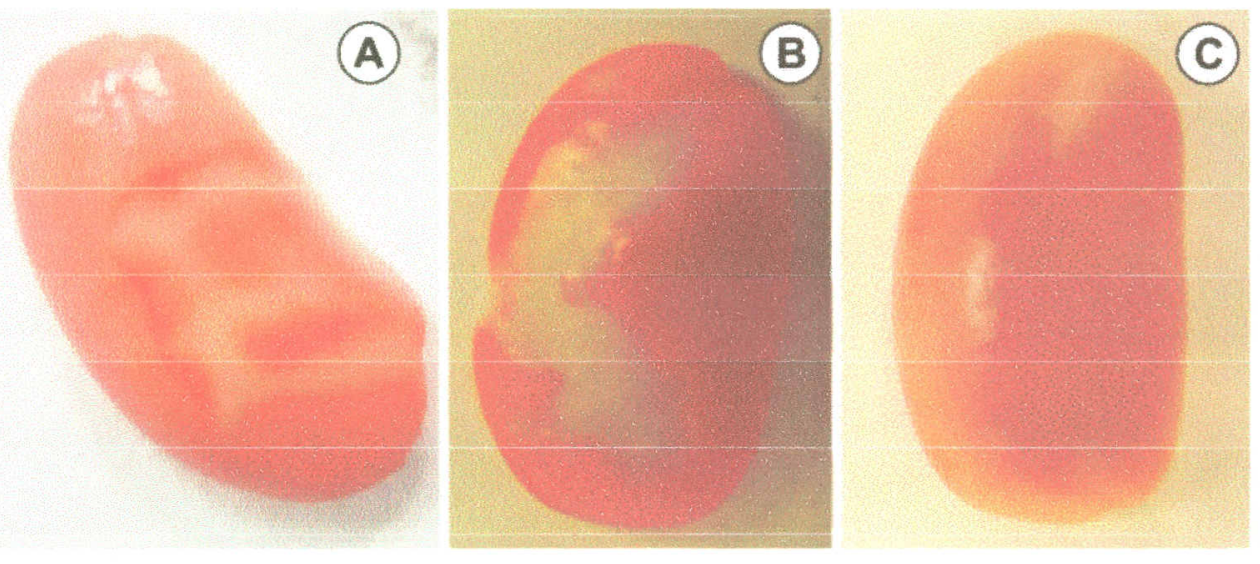
observed when $E$. heros adults fed directly on soybean seeds (Depieri \& Panizzi 2011).

The visual aspect of the seeds damaged by the two different species of stink bugs showed different traits. In the case of seeds damaged by E. meditabunda, the symptons (spotty discolored areas) were more spread out on the seed surface if compared to the damage caused by $E$. heros. (Fig $4 \mathrm{a}$, b). Furthermore, mature seeds attacked by E. meditabunda showed less shrinkage of the tegument when compared to those attacked by $E$. heros; in this last case, damage was apparently deeper (Fig 4b) and seeds showed reduced size. Undamaged seeds showed no discoloration (Fig 4C). Nunes \& Corrêa-Ferreira (2002) observed reduction in seed quality and in germination potential of soybean seeds attacked by $E$. heros in the greenhouse.

Differences in seed damage caused by the two different stink bug species might be related to the shorter length of E. meditabunda stylets (rostrum length of 3.14-3.34 mm) as compared to those of $E$. heros $(5.41-5.63)$ (Panizzi \& Machado-Neto 1992), which might not penetrate deeper in the seed leading to a more superficial damage to the seed, and/or to the presence of distinct salivary enzymes causing different lyses of the seed tissue. Clearly, more research is needed to fully clarify this point.

In conclusion, results of these studies demonstrated that although the Neotropical brown stink bug, E. heros, feeds/stay shorter on the soybean plant than the brownwinged stink bug, E. meditabunda, it induced more severe damage to the cotyledons of soybean, mostly likely due to the higher amylase activity detected in its salivary gland extracts.

Acknowledgments We thank Paula L Mitchell, Winthrop University, USA, Paulo RVS Pereira, Embrapa Trigo, Brazil, and three anonymous reviewers for critically reading the manuscript. We also thank Walter Terra, University of São Paulo for the laboratory support in the salivary enzyme analysis. This research was supported by a scholarship to FACS, JJS, and RAD and research funds to ARP, from the National Council for Scientific and Technological Development (CNPq), Brazil.

\section{References}

Corrêa-Ferreira BS, Azevedo J (2002) Soybean seed damage by different species of stink bugs. Agric Forest Entomol 4:145-150

Costa EC, Link D (1977) Danos causados por algumas espécies de Pentatomidae em duas variedades de soja. Rev Centr Cienc Rur 7:199-206

Daugherty DM, Neustadt MH, Gehrke CW, Cavanah LE, Williams LF, Green DE (1964) An evaluation of damage to soybeans by brown and green stink bugs. J Econ Entomol 59:719-722

Depieri RA, Panizzi AR (2010) Rostrum length, mandible serration, and food and salivary canals area of selected species of stink bugs (Heteroptera, Pentatomidae). Rev Bras Entomol 54:584-587

Depieri RA, Panizzi AR (2011) Duration of feeding and superficial and in-depth damage to soybean seed by selected species of stink bugs (Heteroptera: Pentatomidae). Neotrop Entomol 40:197-203

França-Neto JB, Krzyzanowski FC, Costa NP (1998) O teste de tetrazólio em sementes de soja. Londrina, EMBRAPA-CNPSo, Documentos $11672 \mathrm{p}$.

Galileo MHM, Heinrichs EA (1979) Danos causados à soja em diferentes niveis e épocas de infestação durante o crescimento. Pesq Agropec Bras 14:279-282

Galileo MHM, Gastal HAO, Grazia J (1977) Levantamento populacional de Pentatomidae (Hemiptera) em cultura de soja (Glycine max L. Merr.) no município de Guaiba, Rio Grande do Sul. Rev Brasil Biol 37:111-120

Hori K (2000) Possible causes of disease symptoms resulting from the feeding of phytophagous Heteroptera, p. 11-35. In: Schaefer CW, Panizzi AR (eds) Heteroptera of economic importance. CRC Press, Boca Raton, p 828

Hori K (1972) Comparative study of property of salivary amylase among various heteropterous insects. Comp Biochem Physiol 42B:501-508

International Union of Biochemistry (1961) Report of the comissiono n enzymes of the International Union of Biochemistry. Pergamon Press, Oxford, $p 15$

McPherson RM, Douce GK, Hudson RD (1993) Annual variation in stink bug (Heteroptera: Pentatomidae) seasonal abundance and species composition in Georgia soybean and its impact on yield and quality. J Entomol Sci 28:61-72

Noelting G, Bernfeld P (1948) Sur les enzymes amylolityques. III. La BAmylase: dosage d'activité et contrôle de l'absence d'a-amylase. Helv Chim Acta 31:286-290

Nunes MC, Corrêa-Ferreira BS (2002) Danos causados à soja por adultos de Euschistus heros (Fabricius) (Hemiptera: Pentatomidae), sadios e parasitados por Hexacladia smithii Ashmead (Hymenoptera: Encyrtidae). Neotrop Entomol 31:109-113

Panizzi AR (2004) Neotropical brown stink bug, Euschistus heros (F.) (Hemiptera: Heteroptera: Pentatomidae). In: Capinera JL (ed) Encyclopedia of entomology. Kluwer Academic Publishers, Dordrecht, The Netherlands, p 1545p

Panizzi AR, Machado-Neto E (1992) Development of nymphs, and feeding habits of nymphal and adult Edessa meditabunda (Heteroptera: Pentatomidae) on soybean and on sunflower. Ann Entomol Soc Am 85:477-482

Panizzi AR, Corrêa BS, Gazzoni DL, Oliveira EB, Newman GG, Turnipseed SG (1977) Insetos da soja no Brasil. Embrapa, CNPSo, Bol Tec 1:20p

Panizzi AR, Smith JG, Pereira LAG, Yamashita J (1979) Efeitos dos danos de Piezodorus guildinii no rendimento e qualidade da soja. Anais Seminário Nacional de Pesquisa de Soja 1 Londrina PR v 2 p 59-78.

Pereira PRVS, Salvadori JR (2008) Aspectos populacionais de percevejos fitófagos ocorrendo na cultura da soja (Hemiptera: Pentatomidae) em duas áreas do norte do Rio Grande do Sul. Embrapa Trigo, Comunicado Técnico 253, $10 \mathrm{p}$.

Rizzo HFE (1971) Aspectos morfológicos y biológicos de Edessa meditabunda (F.). Rev Peruana Entomol 14:272-281

Saluso A, Xavier L, Silva FAC, Panizzi AR (2011) An invasive pentatomid pest in Argentina: the Neotropical brown stink bug, Euschistus heros (F.) (Hemiptera: Pentatomidae). Neotrop Entomol 40:704-705

SAS Institute Inc (1998) SAS user's guide: statistics. Version 6.12. SAS Institute, Cary, NC, USA

Taylor GS, Miles PW (1994) "Osmotic pump" feeding by coreids. Ent Exp Appl 73:163-173.

Todd JW, Turnipseed SG (1974) Effects of southern green stink bug damage on yield and quality of soybeans. I Econ Entomol 67:421-426

Villas Bôas GL, Panizzi AR (1980) Biologia de Euschistus heros (Fabricius, 1798) em soja [Glycine max (L.) Merrill]. An Soc Entomol Brasil 9:105-113 